\title{
Emerging Global Partnership: Brazil and China
}

Parceria Global Emergente: Brasil e China

NIU HAIBIN*

Rev. Bras. Polít. Int. 53 (special edition): 183-192 [2010]

\section{Introduction}

As emerging global players, Brazil and China have developed a fullfledged bilateral strategic partnership. During President Lula's two tenures, the partnership has been deepened and broadened with increased global components and implications. The creation of some influential international forums like BRIC summit, G20 summit and BASIC meetings have witnessed the cooperation between Brazil and China. While the global influence of the strategic partnership is a very early phenomenon, it deserves to be investigated since the partnership has been a model for the cooperation between emerging powers.

\section{Emerging Major World Powers}

Both China and Brazil have long thought themselves as natural major world powers while the road to this position was not so straight. Largely based on their geographical size, plentiful natural resources, and singular cultural origin, both nations worked to achieve great power status. Since the establishment of PRC, this is the first time for both countries to enjoy economic booming at the same time. During the rapid development of Brazil in 1960s and 1970s, China was struggling out of its cultural revolution and looking for a new direction. While China began its economy launching in the 1980s, Brazil was tortured by the lost decade. Entering the $21^{\text {st }}$ century, both China and Brazil were perceived together as emerging economies and were listed as the top 10 economies worldwide. A little difference here is that China is a reemerging economy indeed considering its historical status in East Asia and weight in world economy. Such is not the case of Brazil.

Both Brazil and China pursued a peaceful rise and focused on the soft powers such as economy and international law. Brazil's contribution during the Second World War didn't win it a permanent seat at UN Security Council,

* Research Fellow at Shanghai Institute for International Studies, China (haibinniu@gmail.com). 
which made Brazil commit to achieving its world power status by focusing on means of international economy and law. Considering its abandon of a nuclear weapon program, its peaceful settlements of disputes with neighbors, and its promotion of regional integration in South America, it's fair to say Brazil's rise is peaceful. On the other hand, affected deeply by the Cold War system in Asia, China has conflicts with several neighbors. However the mainstream of China's foreign policy is to engage peacefully with its neighbors. To promote economic cooperation has been the main purpose of China's engagement with Shanghai Cooperation Organization, ASEAN, and Asia Summit, among other initiatives. With China late joining WTO, it finally integrated itself to the world economy. It's wiser to deal with so many neighbors through economic integration and regional institutions. To integrate themselves to the world economy also served well for Chinese competitive sectors, namely raw material and human resources respectively.

It took time to transform from emerging economies to emerging powers. President Lula's multilateral diplomacy contributed a lot to Brazil's status as an emerging world power. Regionally, his efforts to resist FTAA, build the regional cooperation framework in South America, rebuild Haiti, and handle the Honduran crisis reflect the administration's independent contribution to regional public goods. Globally, the dialogue with G8, African countries and Middle Eastern counties, the creation of G20, IBSA and BRIC summits, the WTO Doha round negotiation, the role of BASIC in climate change negotiation in Copenhagen and efforts on solving UN security issues like Iran's nuclear program have been leaded by Brazil. These diplomatic efforts made by Lula administration transformed Brazil from a nation representing 2.86\% of world GDP to an influential emerging worldwide power. China, despite its $11.4 \%$ of world GDP and Permanent seat in the UN Security Council, is being required to contribute more significantly in global security issues, otherwise it can't be perceived as a responsible stakeholder in the current international system. As emerging global players, both Brazil and China have a long way to go to transfer their economic power to institutional influence worldwide.

Emerging powers are still not established powers or great powers. Even the most prominent emerging powers like China and India have not been recognized as established powers, and to achieve this goal they have at least 15 years to go. The current dominant international institutions are still the Breton-woods system and post-WWII security organizations. China's discourse in WB and IMF is still very limited and it is still a non-member state of IEA and OECD. Before the first G20 summit in Washington, China was an occasionally invited to the G8's side forum. Brazil enjoyed a similar international status as China's. Additionally, Brazil is not a permanent member of UN Security Council, which reduces its international prestige. Brazil's active role in working out the nuclear agreement with Iran didn't get support by UN Security Council's permanent members. 
The 2008 international financial crisis, however, has provided an opportunity to shorten the gap between emerging powers and established ones, since the strong recovery of emerging powers and the visible improvements of WB and IMF share reforms. The G20, premier forum for international economic cooperation, is a great achievement in accommodating emerging powers into international economy system. Nevertheless, emerging powers still have no access to leadership roles in political and security arenas.

\section{Promising Strategic Partnership}

Since 1993, leaders have begun to talk about the strategic nature of bilateral relationship between China and Brazil. Generational leaders from Franco and Jiang Zemin through Cardoso to Lula and Hu Jintao consistently contributed their political will to establish and consolidate the bilateral strategic relationship. This is the first strategic relationship established by major developing countries in the world. The initial meaning of the strategic relationship is to develop longstanding, stable, and strategic mutual cooperation. Both countries share the identity of major developing states, leading regional players, and big potential roles in world affairs. Based on these common identities and forward-looking thinking, both countries developed a comprehensive cooperative path covering trade, energy and mining, finance, agriculture, quality supervision, inspection and quarantine, industry and information technology, space cooperation, science, technology and innovation, and education, among other areas. Brazil offered China the market economy status. China has been Brazil's largest trade partner, surpassing the US and the EU in 2009. Cooperation between Brazil and China has been the model of South-South cooperation.

The strategic relationship serves both countries' aspiration to play a larger role in promoting world peace and development. Different from an alliance aiming at balancing or constraining other powers, the relationship is a kind of new partnership in the post-Cold War era. A healthy foreign policy of major powers should be diversified and worldwide. The relationship in nature is nonexclusive and win-win oriented. Both countries have strategic relationships with other important global players. The relationship helped both countries to be a part of the dynamic of each region respectively. China has become the member of OAS (as an observer) and IDB with the support of Latin American countries including Brazil. China's engagement with Latin America has been gradually institutionalized, which will make it committed to the support of public goods for the region with the cooperation of Brazil. Chinese police peacekeepers in Haiti serve under the command of a Brazilian General under the UN auspices. In global terms, Central Asia is the only region where Brazil lacks engagement, while the SCO with China as an important member could lend Brazil a hand. 
President Lula enhanced the country's diplomatic efforts to develop its relationship with major emerging powers. This enhancement is expected to promote Brazil's international status in main international organizations, and to find new markets and investments for Brazil. His efforts in promoting the BRIC summit have transformed BRIC from an economic conception to a political reality. The BRIC summit could both enhance the internal cooperation among emerging powers and increase the voice of emerging powers in major international financial institutions. China shares the wisdom of enhancing the cooperation among emerging powers despite its unease about the cooperation's negative effects on its relationship with the developed world and the uncertainty about emerging powers' future development. In a response to the situation of the 2008 international financial crisis, China has increased its political will to enhance its comprehensive cooperation with other emerging powers in the search for new development opportunities and reform of the international financial system. Both the openness of the current international system and the moderate aspiration of BRIC have released China's anxiety. China will host the third BRIC summit after Brazil in 2011, which shows the consistent support of both countries to the cooperation among emerging powers.

At the beginning of the strategic relationship, both sides realized that the implication of the relationship is beyond bilateral dimension. The great potential role in regional and global affairs was the most important impetus for both sides to establish the referred strategic relationship. These potential roles are becoming true in current stage. The international community is more frequently calling on both sides to enhance their cooperation for the solution of the major global issues in the economic, environmental, political and security issues. Regional, multilateral and global issues are becoming important topics of the Strategic Dialogue between both Chancelleries. In this regard, Presidents Lula and $\mathrm{Hu}$ Jintao signed the Joint Action Plan Brazil-China 2010-2014 in Brasilia on April $15^{\text {th }}, 2010$. The joint action plan is a cornerstone of the strategic relationship. Besides the comprehensive bilateral cooperation agenda, both sides committed to cooperate on the broadest multilateral issues since the establishment of the strategic relationship. According to the joint action plan, amongst the abovementioned multilateral issues are arms control and climate change, coordination in UN, WTO, and G20, support of cooperation mechanisms for major developing countries, need to safeguard the rights and interests of developing countries, and inter-regional cooperation between Asia and Latin America and Caribbean.

\section{Challenges for a Global Partnership}

As emerging global players, both Brazil and China are constrained by their heavy domestic agenda, thus they are inward-looking countries to some extent. The Brazilian public has not even begun to debate the ramifications of Brazil's 
new prominence, not to mention examining the potential costs and commitments involved. ${ }^{1}$ Poverty, inadequate public education, corruption, and public violence remain problems to be solved by further development in Brazil. Under the leadership of President Lula, Brazil has made important achievements in fighting hunger, building infrastructure, and accumulating foreign reserves by continuing market-friendly economic policies and stimulating private investment. By its continued high economic growth, the country has earned more resources to provide external public goods. Brazil has, in that sense, contributed its first US $\$ 10$ billion to IMF by purchasing its bonds. China, on its side, faces the challenge to enlarge its domestic consumer market and the economic structure transition to a more efficient and sustainable one. The domestic agenda and poor resources restrain the capacity of both countries to play a larger role in world affairs, but they are working hard to integrate their economies to world economy to overcome these shortcomings. In the long run, this strategy will work out finally.

To build a global and strategic partnership, both sides need to enhance the understanding of each other in terms of economy, society and culture beyond politics. There are some difficulties such as language, geographic distance, and economy frictions obstructing the mutual understanding. Lack of Brazilian newspapers, magazines or media in English make it difficult for the Chinese to know a great deal about Brazil. There is no influential research institute focusing on China in Brazil. Brazil's advanced economic structure, higher per-capita GDP, universal usage of bio-fuel, and other characteristics were unknown to many Chinese until the very recently. However, under the emphasis of the leaders to the importance of each other, scholars, entrepreneurs and travelers from both sides are beginning to have increasing interest in their counterparts. Centers of Brazil Studies have been established in China's influential think-tanks and universities with the development of public diplomacy in China, CCTV-news is trying to introduce China's voice to the world, and more Brazilians will have chances to know China further. Great events like Olympic Games 2008, World Expo 2010, hosted by China, and World Cup 2014 and Olympic Games 2016, hosted by Brazil, have been and will offer great opportunity to mutual knowledge and understanding. The soft power resources of Brazil, such as soccer, Samba, beautiful cities, and renewable energy, impress Chinese very much. The Chinese now know that they can import not only iron ore and soybean from Brazil but also regional jets and biotechnology. The Cultural Month of China in Brazil is planned for 2010, and a similar event for Brazil will be held in China in 2011. These cultural activities plus educational exchange programs will be helpful to deepen the ties across both societies.

1 DIAZ, Miguel and ALMEIDA, Paulo Roberto, (2008). Brazil's Candidacy for Major Power Status, published at [http://www.stanleyfoundation.org/articles.cfm?ID=504]. Available on 11/01/2010. 
Though Brazil and China have a balanced and sustainable trade relationship, there are still some concerns about the bilateral trade model. Brazilian exports to China rely mainly on raw materials and food products, which lead to the worry of de-industrialization in Brazil. This perspective fails to notice that Brazil also exports manufactured products to China and the raw-material and food sectors only constitute a small part of Brazil's economy. Trade with China in the recent decade has improved the trade condition of Brazil and contributed a lot to its export promotion in the condition of real appreciation. Bilateral trade showed spectacular growth of 780 percent since the beginning of Lula's administration in 2003, and reached 36 billion dollars in 2009 in spite of the global economic crisis. Furthermore, the booming trade relationship with China also serves Brazil's trade strategy to diversify worldwide. China is not only a purchaser and consumer, but also an investor. Sectors of Brazilian mining, IT, infrastructure and the newfound oil field have got vast Chinese investments. Brazil initiated a China Agenda in 2008 to identify the priorities in bilateral trade and investment, which is very helpful to find win-win ways. Brazil highly values the cooperation on the Earth Resources Satellites with China, and looks forward to the cooperation on bio-fuel and bio-energy. The cooperation between financial sectors is also getting impetus in recent years. Actions such as to intensify macroeconomic policy dialogue, strengthen cooperation in multilateral financial forum, expand bilateral financial cooperation and facilitate trade finance by promoting the use of local currencies in bilateral trade have been listed to the 2010-2014 Joint Action Plan. It seems that most Brazilians are beginning to treat China as an opportunity other than a pure competitor or even a threat.

Brazilians often complain that since we both countries are strategic partners, why doesn't China back Brazil's bid for a permanent seat at UN Security Council? In 2005, China opposed to an increase in the number of permanent members in the Security Council, which Brazil seeks as a member of G4 together with Japan, Germany and India. China explained that its opposition was addressed to Japan and India, rather than Brazil, without expressing obvious support to Brazil. The distress of Brazilian UN representatives remains since China doesn't offer its formal support to Brazil while, in past times, Brazil recognized China as a market economy. The opposition of the U.S., Mexico, and Argentina on this issue released Brazil's pressure on China temporally. Unlike the neighbors with territorial disputes and historical differences, Brazil should be the most possible candidate to get China's support on biding for the permanent membership of UN Security Council, considering its comprehensive power, regional leadership, contribution to UN peace activities, and closer relationship with China. is the possibility of a consensus between US and China, support of regional peers, and the substantial improvement of China's relationship with Japan and India will have great influence on China's final decision.

The political will and consensus on treating each other as emerging global player are not very strong for both sides. Except for China's experts' dealing with 
Brazil and other emerging powers, the usual focus on great powers still treats traditional powers, rather than emerging powers, as influential global players in. Cooperation with the U.S. will continue to represent the first priority in Chinese foreign policy, which seems to be the consensus within the policy-research circle. The shift to priority on the cooperation among emerging powers is only a very recent topic.

Initiative to focus on developing cooperation with South countries under President Lula has also led to debates in Brazil. Most of the emerging powers do see themselves as beneficiaries of the current international system, and try to maintain good relationship with traditional powers especially the U.S.; what dissatisfies emerging powers in this context, though, is their lower status in it. Indeed, the strategic dialogues with the U.S. and Brazil are the most influential ones in China's cooperation with traditional powers and emerging powers respectively. Because of their different influence to the external world and domestic influence, it takes time for both China and Brazil to treat each other as the same level as strategic partner as the U.S. enjoys.

\section{Others' Perceptions of the Global Partnership}

As BRIC members, both Brazil and China have attracted increasing individual attention from the international community; nevertheless, some countries still consider their international role through the framework of cooperation among emerging powers. Except for the IBSA, both China and Brazil are members of the forums such as G5 (Brazil, Mexico, India, China and South Africa), BASIC (Brazil, South Africa, India and China), and the BRIC summit. Some observers defend the idea that both countries seek a stronger and more influential place in international affairs and both would welcome a more constrained role for the United States. Cardoso's and Lula's approach to India, South Africa and China since the 1990s have had twin goals of economic diversification and political balancing of U.S. power. ${ }^{2}$ China can't press the dollar status as the world currency only by doing the same with other creditors. "The only Chinese statement that created pressure on the dollar came in June, when BRIC leaders called for a 'more diversified currency system' in their communiqué. Again, the effectiveness of financial statecraft improved when a concert of creditors sounded out a common position." 3 These observations show that when both China and Brazil can't effectively affect the main governance structure of world affairs individually. When they have a common voice, it might work.

To balance or constrain the hegemonic behavior or hegemonic power has been a major concern in some U.S. think tanks. The increasing tendency of

2 DOMINGUEZ, Jorge I., (2006). China's Relations with Latin America: Shared Gains, Asymmetric Hopes, published at [http://www.offnews.info/downloads/china-latam.pdf]. Available on: 10/05/2010.

3 DREZNER, Daniel W., (2009). Bad Debts: Assessing China’s Financial Influence in Great Power Politics. International Security, Vol. 34, No. 2, p. 40. 
emerging powers to have a more independent foreign policy has severed such concern. Even though both China and Brazil are trying to rise with the West other than against the West, their enlarging role is difficult to be welcomed by the West. China's cooperation with other emerging powers including Brazil on diversifying world currencies and unifying as a group at Copenhagen Climate Conference was considered by leading powers as arrogant behavior. President Lula's involvements in the issues of Honduras crisis and Iran nuclear program have led to some difficulties in Brazil's relations with the U.S. Even though both Brazil and China don't like to be perceived as alliance aiming at anti-America, they do have a tendency to play a more independent role in solving global issues based on their national interests and self-experiences. This kind of concerns reflects instabilities in the transition of power. The Obama administration has initiated a strategy of multi-partners to solve the pressing global issues. The strategy is the most adequate way of regarding the nature of global issue and shifting power structure. The challenge here for all is to understand partnership and cooperation on the right basis, which means they have to accommodate different approaches, interests and values. Despite the above difficulties, both Brazil and China are perceived as moderate forces within the BRIC group.

The third perception is that the strategic partnership has little global influence since it has done little in world affairs. Because countries such as China, India or Brazil are emerging rapidly, they are willing to raise their international status by taking the lead in new "non-Western" international organizations and to gather media attention through summit diplomacy. ${ }^{4}$ This perception reflects the fact that cooperation among emerging powers is still in its early stages in terms of their different capacity, political system, international status and economic competition. Some countries even expected Brazil to press China to make economic sacrifices for the sake of the global environment. Despite failing to fulfill the expectation, the first-ever BRIC communiqué created some influence when it called for "urgent action" regarding larger say in the international financial institutions. With an institutionalized dialogue and cooperation, the global dimension of the bilateral strategic China/Brazil partnership will appear gradually.

\section{The Way Ahead}

During the two terms of President Lula's administration, the global dimension of the strategic partnership between Brazil and China has been emerging. Brazil under the leadership of President Lula aims to transform its power resources into real international influence and status. With this active global engagement policy, Brazil becomes an emerging global player in terms of either geography or area issue. The Lula era has witnessed the cooperation in

4 RENARD, Thomas, (2009). A BRIC in the World: Emerging Powers, Europe, and the Coming Order. Gent: Academia Press, p. 19. 
Haiti peace-keeping task, Doha round negotiation, Copenhagen negotiation and the reform of international financial institutions, etc. President Lula's emphasis on cooperation with major developing countries has led to international forums based on the membership of China and Brazil. China has consistently contributed itself to develop the strategic relations with Brazil. The current bilateral strategic relationship is becoming full-fledged with an increasing international agenda.

To make the strategic partnership get more sustainable, both sides should deepen their knowledge about each other and commit more energy to cultivate the ties between the two societies. China has been put into the center of world affairs in terms of the Strategic and Economic Dialogue between the United States and China, which attracted the main attention of the strategic studies in China. The 2008 international financial crisis told a lesson to China that it is dangerous to put all eggs in one basket. The geopolitical effects of the financial crisis are putting the emerging powers closer. The mutually beneficial economic cooperation between China and Brazil will continually be the foundation of bilateral relationship. Beyond that, China should pay more attention to the potential big role of Brazil in the fronts of environmental protection, containment of climate change, global energy and food security, international development agenda, and global trade system. Enlightened recognition of Brazil's big potential will help to keep a dynamic strategic partnership.

The regional and global implications of the bilateral strategic partnership won't come naturally. To deliver real public goods, regionally and globally based on sustainable domestic economic development, is the only way to realize the strategic partner's global impacts. Both countries could work through the regional financial institutes to support regional infrastructure, finance small businesses and reduce poverty. At the global level, they can continue to promote the reform of major political and economic institutions together with other major emerging powers, and make them more representing of the developing world's interests. Though both countries share common positions in dealing with global challenges like climate change, they do have some kind of gap in preparing themselves to the challenge. This kind of gap, differences or approaches should be frequently coordinated on high level dialogues. As emerging powers in world stage, Brazil and China live in a new era characterized by inter-dependence and global challenges, an era when great opportunities are offered to achieve their great power dream in transforming the current international system.

\section{Principal References}

ALDEN, Chris and VIEIRA, Marco Antonio, (2005). The New Diplomacy of the South. Third World Quarterly, Vol. 26, No. 7, p. 1091.

DIAZ, Miguel and ALMEIDA, Paulo Roberto, (2008). Brazil's Candidacy for Major Power Status, published at [http://www.stanleyfoundation.org/articles.cfm?ID=504]. Available on $11 / 01 / 2010$. 
DOMINGUEZ, Jorge I., (2006). China's Relations with Latin America: Shared Gains, Asymmetric Hopes, published at [http://www.offnews.info/downloads/china-latam.pdf]. Available on: 10/05/2010.

DREZNER, Daniel W., (2009). Bad Debts: Assessing China's Financial Influence in Great Power Politics. International Security, Vol. 34, No. 2, p. 40.

O'NEIL, Shannon, (2010). Brazil as an Emerging Power: the View from the United States, published at [http://www.cfr.org/publication/21503/brazil_as_an_emerging_power.html], Available on 01/04/2010.

ONIS, Juan de, (2008). Brazil's Big Moment. Foreign Affairs, Vol. 87, No. 6, pp. 10-122.

RENARD, Thomas, (2009). A BRIC in the World: Emerging Powers, Europe, and the Coming Order. Gent: Academia Press, p. 19.

ROETT, Riordan, (1975). Brazil Ascendant: International Relations and Geopolitics in the Late $20^{\text {th }}$ Century. Journal of International Affairs, Vol. 29, No. 2, p. 139.

SCHNEIDER, Ronald M., (1976). Brazil: Foreign Policy of a Future World Power. Boulder: Westview Press, pp. 32-43.

WILLIAMSON, John, (2003). Lula’s Brazil. Foreign Affairs, Vol. 82, No. 1, p. 110.

VAZ, Alcides Costa, ed., (2006). Intermediate States, Regional Leadership and Security: India, Brazil and South Africa. Brasilia: University of Brasilia, pp. 1-310.

Received June 30, 2010

Accepted November 11, 2010

\section{Abstract}

The Lula era has witnessed a changing bilateral strategic partnership between China and Brazil, having the interlocutions between both countries became more substantial, comprehensive and influential. To enlarge the global impacts of the partnership, both countries should inject more regional and global components into their bilateral agenda. In doing so, both sides need to enhance the ties not only in terms of economic cooperation but also of social interaction.

\section{Resumo}

A era Lula testemunhou que a parceria estratégica entre China e Brasil tornou-se substantiva, ampla e influente. Para aumentar o impacto dessa parceria, os dois países devem inserir mais componentes regionais e globais na agenda bilateral. Fazendo isso, os dois lados fortalecem os laços não só em termos de cooperação econômica, mas também em termos de interação social.

Key-words: Brazil; China; global partnership.

Palavras-chave: Brasil; China; parceria global. 